\title{
The changing educational needs of subject librarians: a survey of UK practitioner opinions and course content
}

\author{
Martin Simmons and Sheila Corrall, Information School, University of Sheffield, UK
}

Corresponding author: Professor Sheila Corrall, Information School

University of Sheffield, Regent Court, 211 Portobello Street, Sheffield S1 4DP

Tel +44(0)114 2222632, Fax +44 (0)114 2780300, Email s.m.corrall@sheffield.ac.uk

The fitness for purpose of professional education for library work has been constantly debated. Librarianship education and library practice have changed significantly as a result of technological, social and other factors affecting information provision and use. The key role of subject librarian in academic libraries has been particularly affected by both technological and pedagogical developments that have transformed the information arena, expanded their teaching activities and raised questions about the relevance and value of contemporary library-related courses for their present hybrid responsibilities. An investigation of UK course content and practitioner opinion was conducted in summer 2010 to explore whether existing programmes offered suitable preparation for current subject librarian roles. A pragmatic mixed methodology combined document analysis of course content with a mainly quantitative sector-wide survey of subject librarians $(n=65)$ and library managers $(n=48)$, followed by interviews with 8 librarians and 7 managers. Quantitative data were analysed using descriptive statistics and qualitative data were analysed thematically. Results showed generally positive opinions of UK library education, but revealed different priorities among the two groups and a strong desire among subject librarians for improved coverage of pedagogy. Findings confirmed that personal qualities are at least as important as specialist abilities for contemporary librarians.

Keywords: academic libraries, liaison librarians, librarianship, library science, professional education, subject librarians, university libraries.

\section{Introduction}

The literature shows that the role of the academic librarian has changed significantly in the last few decades. The most frequently mentioned changes are the increased teaching role that academic librarians have - teaching information literacy (IL) and library skills - as well as increased liaison with faculty [1-3]. In addition, there is more involvement with ICT and the Web; in recent years, e-learning, virtual learning environments (VLEs) and Web 2.0 have increasingly been used to facilitate learning and to adapt to the changing expectations and learning habits of students [4-7]. The academic library itself is increasingly becoming more like a gateway to information and a learning centre rather than a library in the traditional sense $[1,8,9]$.

Terms such as "hybrid librarian" [10,11] and "blended librarian" [4] have been used to distinguish the modern role of the academic librarian from that of the past. Kanczak and Szołtysik state that "the model for a hybrid librarian does not have much in common with a stereotypical librarian, except in lending books" [11]. Today's academic librarians need a diverse set of skills, knowledge and competencies, many of which have not traditionally been associated with librarianship [12]. Library managers are increasingly valuing general and personal skills over traditional librarianship skills [3,13-16]. 
There has also been much change within library and information science (LIS) academia. Many library schools have changed into more academic information studies or information science departments, reflecting their increasing focus on research rather than vocational librarianship training [17]. Audunson argues that library course curricula have been changing to become more academic (information science-based) and less professional (traditional librarianship) [17]. However, some commentators, notably Michael Gorman [18] do not approve of the direction in which librarianship education is moving and want library courses to revert to the more traditional focus they had in the past.

The focus of the study reported here is whether today's UK postgraduate library-related courses are adequately preparing graduates for academic library work in the changing context described and in particular for the role of subject librarian (SL), which is one of the most common within the sector. The investigation included primary research on the views of SLs and library managers (LMs). There is a moderate amount of recent UK literature relating specifically to SLs, to which this study's findings can be compared [9, 19-23], but surprisingly little research specifically on their professional education.

The existing research on the views of LIS graduates is of limited value to this study because much of it is too old to reflect recent changes in the profession, is based on one institution (the University of Sheffield) and covers areas of information studies not directly related to librarianship [24-27]. There is also a lack of literature regarding academic LMs' views on their employees' professional education and skills. These are the gaps in the literature this study aimed to address.

The central research question was: "Is postgraduate librarianship education in the UK suitably preparing students for the role of subject librarian?" The aim of the study was to investigate the content of UK postgraduate librarianship courses and to discover, based largely on the views of library managers and subject librarians, their suitability in preparing students for academic library work as subject librarians. More specifically, its objectives were to investigate:

- What is being taught on library courses?

- What is the role of the subject librarian?

- What skills, qualities and knowledge do subject librarians need?

- What are library managers' and subject librarians' views on librarianship education?

- What do they think should be taught on library-related courses?

The study was conducted in the spring and summer of 2010, with the fieldwork taking place between June and August. Section 2 reviews the literature providing the background to the study, section 3 outlines the research methodology and section 4 presents the key findings with reference to relevant literature. The paper is based on an unpublished masters dissertation, which provides fuller details of the study and the instruments used [28].

\section{Literature review}

\subsection{The changing role of the academic library and librarian}

Technology has led to students' changing expectations of the service they want and expect from the library [29-30]. Students increasingly want to be self-sufficient with their research, often without having to go to the library $[9,30]$. Thus the academic library is seen less as a physical place and more as a network and a virtual source of information resources $[1,9]$. Today's academic libraries are more like gateways to information rather than repositories of documents, as they were before computer use became ubiquitous [8,9].

It has been argued that the "hybrid library" (containing both print and electronic resources) and the "hybrid librarian" (with skills transcending traditional librarianship) are necessary to deal with the effect of technology on academic libraries [10,11]. Paterson says of academic 
librarians, "we still need our full range of librarian skills, but that we are also resembling more our colleagues in the computer unit and our colleagues in academic departments" [7]. Bell and Shank believe a "blended librarian" is needed - a role which involves increased understanding of educational technologies and instructional design, teaching, IT, increased liaison with faculty and collaboration with technologists [4].

Academic librarians are increasingly involved in IL education [1-3]. The growing popularity of the Web as a resource means students have access to information not formally approved by the library as reliable and suitable [2,29]. In addition, increased accessibility via technology has meant increased complexity of information retrieval [31,32]. Thus the need for students (and staff) to be taught how to find, evaluate and apply information is greater than ever [2,32]. Brown et al. have argued that many students are "techno-savvy", but lack the IL skills to take advantage of this [33].

The teaching role in an academic library is often the responsibility of SLs [9,20]. In the early 2000s, Biddescombe [20] and Pinfield [23] predicted that more and more job titles would reflect SLs' increased teaching role. However, a recent study by Bewick and Corrall found that very few job titles (4 out of 82) in their SL sample did so [19]. Feetham believes that the increased liaison between librarians and faculty (often to collaborate on IL strategies) is reflected by changing job titles such as "faculty liaison librarian" and "academic liaison librarian" [9]. Recent surveys [19,21] have found "liaison" job titles are now common, but there are no comparable studies from the previous ten years to establish whether there has been an increase.

\subsection{How should librarianship be taught?}

One debate in the literature is on the extent to which library education should be "academic", involving wider aspects of information science, and on the extent to which it should be "professional", focusing on traditional librarianship skills and knowledge, such as cataloguing, bibliography and reference work, and the history and values of librarianship [34].

Crowley and Brace argue that theories of information are rarely of relevance to the reality of working in a library [35]. However, Audunson suggests that although teaching theory during library courses may mean students are less prepared for library work after graduation, in the long term their contribution and understanding may be greater because of their increased theoretical knowledge [17]. This was partially confirmed by Loughridge, who did a follow-up study of Sheffield MA Librarianship graduates and found that many respondents said some theoretical aspects of the course such as management, that seemed to be irrelevant in their first professional posts, later become useful when they moved into more senior roles [24].

The Chartered Institute of Library and Information Professionals (CILIP) and the American Library Association (ALA) emphasise the importance of theory and practice being included in accredited courses [36,37]. However, they give no advice on the appropriate proportions of professional and academic course content. Audunson [17] and Stoica [38] argue for an appropriate balance without the academic side becoming too dominant over the professional. Audunson argues that without this balance librarianship education is in danger of becoming too fragmented; he believes this has happened in recent years [17].

Some have accepted the influence of information management/science on librarianship: Stoica writes that "we must accept the evolution of information management as being a part of the philosophy of this field [librarianship] and expressing the future of libraries" [38]. However, Gorman claims that library courses are being negatively influenced by information science, which he considers to be "at best, peripheral to professional library work, and, at 
worst, inimical to it" [39]. The result, he believes, is that "many library school graduates lack basic education in the central processes of librarianship" [18].

Another debate mentioned in the literature is the extent to which librarianship education should be focused on teaching practical skills or on principles. Studies from the University of Sheffield report that MA Librarianship graduates' most common complaint about the course was that there was not enough focus on the practical skills needed to work in a library [2426]. One practical skill discussed in the literature is cataloguing. Bowman claims that cataloguing is no longer considered a necessary core topic of library education [40]. Bowman [40] and Gorman [18] believe it is a fundamental part of librarianship and should be treated as such within library courses; without it, they claim, students are unprepared not just for cataloguing, but also for areas that rely on it, such as reference librarianship and collection development.

However, according to Budd, there are also calls for less focus on practical content [5]. The Association for Library Collections and Technical Services (ALCTS) states that "the task of all those involved in educating librarians and other information professionals is to teach principles. These principles include the values of the profession and the reasons for their existence" [41]. ALCTS claims that library courses should not focus on specific library tasks and the skills of the job, but should prepare students for a process of lifelong learning throughout their career, that is, continuing professional development (CPD) [41]. CPD is considered important because the fast-changing nature of academic librarianship means that skills constantly need to be updated [11,12,20,29,42]. CILIP [36] and the ALA [37] emphasise that undertaking CPD is a key part of the information profession, and for course accreditation they require evidence that this is promoted to students.

\subsection{Skills, qualities and knowledge of academic librarians}

Predictably, given academic librarians' involvement with information and communication technology (ICT), studies show that ICT skills are becoming more sought after by library employers [3,16]. Based on content analysis of job advertisements on the ALA website, Mathews and Pardue argue that certain ICT skills are particularly in demand, namely "web development, project management, systems development, and systems applications" [16]. As well as excellent ICT skills, Hallam and Calvert claim that academic librarianship's multidisciplinary nature means that librarians need skills covering information law, teaching, psychology, management and human resources [12]. CILIP [43] and the ALA [44] emphasise the importance of human and financial management skills for information professionals. With library budgets generally decreasing, Johnson stresses the increased need for academic library staff to have commercial awareness and marketing skills [29].

Garrod [10] and Kanczak and Szołtysik [11] claim that the most important factor for a successful information professional is the right personal qualities and skills. Since librarianship is essentially a service-orientated profession, good social skills are essential $[11,42]$. As Cronin comments, "the introverted, bookish loner is clearly the antithesis of the type of individual sought by employers" [45]. Analysis of library job advertisements by Lynch and Smith in America [15] and Kennan et al. in Australia [14] found that conventional librarianship skills over the years have become less important for employers, whereas personal skills such as creativity, flexibility, and communication have become increasingly important; these were seen as necessary to deal with the impact of rapid change within the profession. Goulding et al. also comment that "[library] employers place a high premium on personal attributes such as enthusiasm, initiative, flair, interpersonal skills and commercial awareness" [13]. 


\subsection{Summary}

There is a consensus that librarianship education has changed significantly in the last few decades and that it will continue to do so in the near future. However, there is disagreement over whether this is a good or bad thing and over the direction needed. Furthermore, the wider context is also significant: that of the changing role of the academic librarian, of the library/information school, and of the academic library/information service itself. New skills and knowledge are required of academic and subject librarians, especially ICT and teaching skills, as well as the ability to learn quickly and adapt to changes in the profession. Personal skills and skills not traditionally associated with librarianship are becoming more important to employers, and the diversification and modernisation of academic librarianship has led to some claiming that a new type of academic librarian is needed - a "hybrid" or "blended" librarian.

\section{Methodology}

The study employed a pragmatic mixed-methods approach, combining document analysis, online questionnaires and email interviews in a sequential design, that used data gathered from successive phases to inform subsequent data collection, increase validity of the findings and form a truer picture of the overall situation through triangulation of methods and data. Different sampling methods were adopted for each phase in line with the pragmatism of the approach and the instruments were tested and piloted before use. A review of related literature was used to inform the design of data collection instruments and to provide contextualisation and points of comparison for the results.

Document analysis of library course content was the primary method used to investigate what was being taught on UK postgraduate library-related programmes, defined here as programmes with the word "library" (or its variants) in the title and/or evidence of a significant library focus in a description of its content or purpose. The websites of the British Association for Information and Library Education and Research (BAILER) and the Chartered Institute of Library and Information Professionals (CILIP) were used to identify candidates for investigation and 14 universities were selected as meeting the criteria of being UK-based and having programmes with a library focus. The course-content analysis included qualitative narrative description of the topics covered and of the similarities and variability between courses, which were then related to issues in the literature and the results of other phases of the study. The analysis was limited to documentation in the public domain available from institutional websites.

A quantitative survey was chosen as an appropriate method for gathering information and opinions in a standardised format from a geographically dispersed population within a limited timeframe. Questionnaire invitations were sent via email to 304 SLs and 254 LMs drawn from as many as possible of the total population of UK universities, identified through the UK government's Department for Business, Innovation and Skills (BIS) website. A pragmatic procedure with systematic and convenience elements was used to select potential participants from staff lists on university library websites, aiming to recruit SLs from both humanities/social sciences and science/technology subject areas and LMs involved in supervising and recruiting SLs. Two separate questionnaires for SLs and LMs were compiled and administered using the SurveyMonkey tool, containing 17 and 10 substantive questions respectively, with eight questions common to both samples and others tailored to their different roles. The design used multiple-choice tick-box questions of varying types (specified, ranked and scaled) to facilitate completion and analysis, with some comment 
boxes to enable participants to add to or clarify responses. Sixty-four SLs and 48 LMs responded to the survey, giving response rates of $21 \%$ and $19 \%$ respectively.

Semi-structured interviews were conducted by email with 8 SLs and 7 LMs to extend the questionnaire data by exploring issues of interest at a deeper level, Purposive sampling was used to select interviewees from questionnaire respondents whose comments were particularly interesting and who had indicated their willingness to participate. Asynchronous email interviews enabled convenient access to busy geographically-dispersed participants and provided accurate records of conversations, strengthening descriptive validity of the findings. The same set of six open questions was used with the two groups to facilitate cross-group comparisons of opinions.

Quantitative data were analysed with descriptive statistics, using the survey tool and spreadsheet software. Qualitative data were analysed in an iterative process using successive levels of coding to define topics, themes and concepts of interest and related to the study objectives. Participants were assigned numbers to protect their identity and all data were anonymised prior to analysis. In the following discussion, interview participants are referred to as SL1, LM2, etc. (denoting respectively the first Subject Librarian interviewee and second Library Manager interviewee) and the abbreviations SLQ and LMQ are used for the two questionnaire surveys.

\section{Results and Discussion}

\subsection{What is being taught on library courses?}

Some topics, such as research methods and information retrieval, appear in almost all courses as core units or as a significant part of a core unit. Cataloguing and classification, despite reports to the contrary (for example, by Gorman [18]), was part of the core content of all 14 courses examined. However, they did not all include practical cataloguing and classification content, something that Bowman believes is essential [40].

Seven courses had Web design as a core unit or a significant part of a core unit, reflecting the new skills required of the "hybrid" and "blended librarian". Given the importance of ICT within academic librarianship, it was interesting that only two courses had core units devoted to ICT, but this probably reflects its pervasive role in information work and a general assumption that course entrants will already be computer literate.

Analysis of optional units revealed significant variety in the number of electives available (ranging from 5 to 13) and in the number that could be chosen (one to three), as well as in the subject matter of the units offered. Some optional topics, such as health information, were very common; others were unique to specific institutions, such as 'Music Librarianship' at Aberystwyth. Five (out of 14) courses did not offer any optional units.

A recurring theme in the literature [1-4,19-21,23] and also in our findings, is the need for academic librarians to have teaching skills. However, only three institutions (Sheffield, Manchester Metropolitan and City) offered optional units with a significant focus on education and teaching.

\subsection{What is the role of the subject librarian?}

\subsubsection{Job titles}

Feetham [9] believes SL job titles have changed to reflect their increased focus on liaison and recent studies [19,21] confirm the adoption university libraries of titles including the word "liaison", but not to a widespread extent, with Subject Librarian (or a title combining the subject name with "librarian") remaining the most common title. The present study (like previous research) found a wide variety of titles, but liaison-related titles (Liaison Librarian 
or variants on that theme, such as Academic Liaison Librarian or Faculty Liaison Librarian) were the dominant group, reported by 21 respondents (almost one-third of the SL sample), significantly outnumbering the 14 Subject Librarians, even if related and hybrid titles (such as Subject Liaison Librarian) were counted in this group.

However, the results here do not support earlier predictions by Pinfield [23] and Biddescombe [20] that the increased teaching role of SLs would lead to more job titles indicating a teaching focus. Only one respondent, a Research and Learner Support Officer, had a title with an educational focus, which is proportionately fewer than the 4 out of 82 identified by Bewick and Corrall [19].

\subsubsection{Job content}

SLs were asked to record (on a four-point scale) how frequently they performed a list of 23 tasks derived from the literature on subject librarians. Fig. 1 shows the nine tasks identified by four-fifths or more of the respondents as performed "very frequently" or "fairly frequently". Among these were four tasks widely recognised in the literature as key responsibilities of SLs - liaison, enquiries, IL teaching and collection management performed "very frequently" by more than two-thirds of the sample. These results broadly confirm the profile revealed by the data collected five years earlier from Hardy and Corrall's smaller sample [21], where liaison, IL training, enquiries, user guide production, collection management and budget management were highlighted by a similar proportion of respondents; the main difference between the previous and present SL samples is the much lower level of engagement with e-learning found in the earlier study (with only half of the sample involved), which confirms Bell and Shank's vision of SLs blending expertise in educational technology with their traditional skillset [4]. Both the present study and the earlier one confirmed cataloguing and classification as a minority activity for SLs, carried out by routinely by only around one-fifth of each sample.

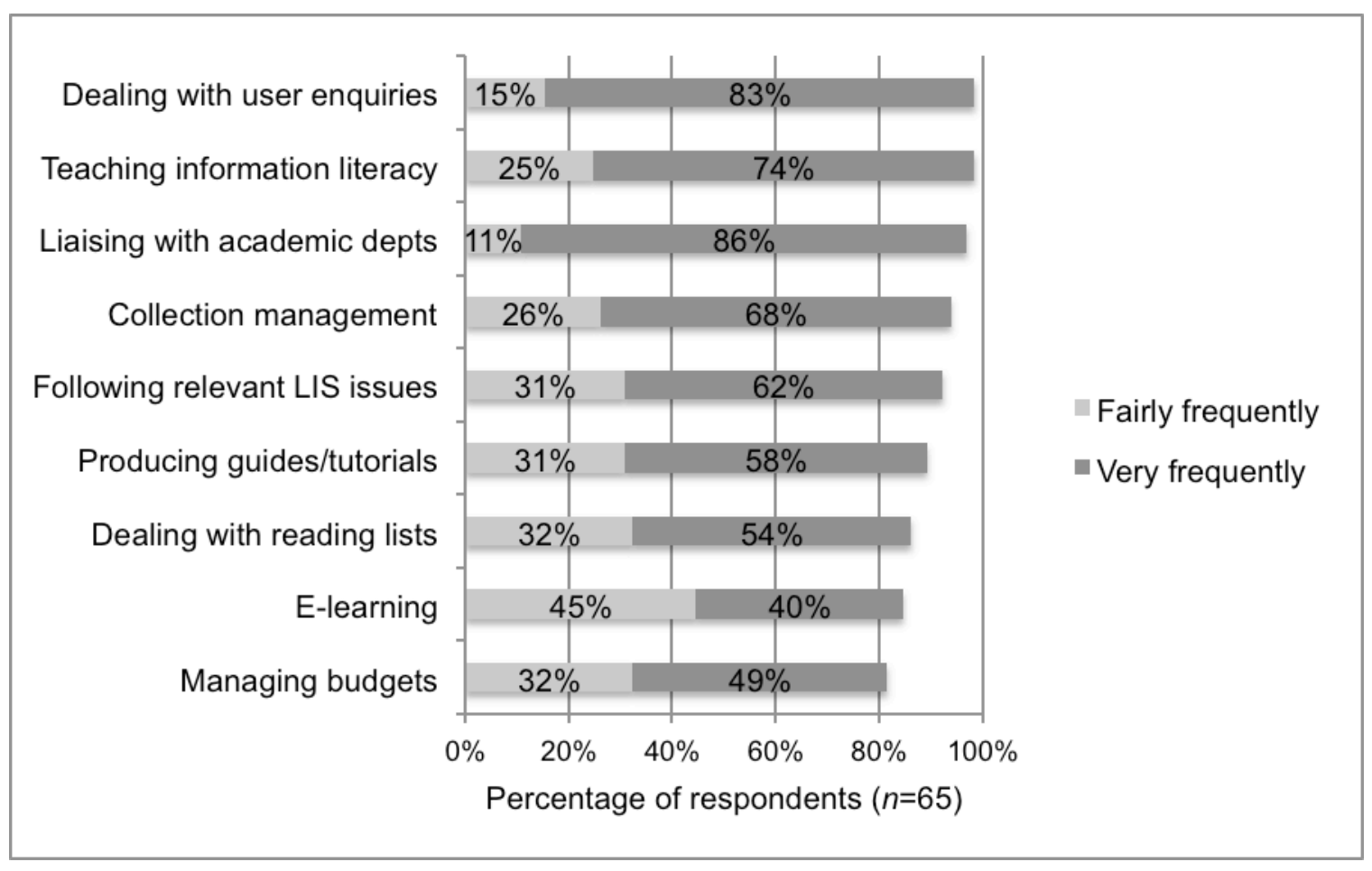

Fig. 1. Most frequent tasks of subject librarians 
Some traditional librarianship tasks remain prominent parts of the SL role, but the nature of the tasks has obviously changed over the years. In relation to enquiries, for example, SL4 said, "the virtual reference desks etc. mean that we are helping more students than ever, but having slightly less contact with the students that we are helping". On collection management, one LMQ respondent said that "the massive upsurge in Amazon e-book sales should indicate, if it hasn't already, that subject librarians have to move into wider areas of LIS development than book-based collections". Furthermore, LM1 said that "resource and financial management has become more prominent as well, particularly managing the large ejournal packages", reinforcing Blin's comments about the pressure on many academic librarians to manage the increasing amount and cost of electronic resources [1].

\subsubsection{Changes in roles}

SLs were asked to identify where time spent on the 23 tasks specified had increased or decreased over their career. The only notable decrease was cataloguing and classification, reported by more than $40 \%$. One LMQ respondent described cataloguing and classification as one of the "comfort zone jobs that could be done by senior library assistants". SL7 said that cataloguing by academic librarians had also reduced because many books are now already catalogued when the library receives them. Fig. 2 shows that the ten tasks with the most noticeable increases reflect developments reported in the literature, as discussed in section 2: SLs are increasingly teaching IL and library skills [1-3]; liaising with faculty/academic staff $[4,9,23]$; and exploiting technology, such as e-learning and Web 2.0, to facilitate communication and learning $[5,6]$.

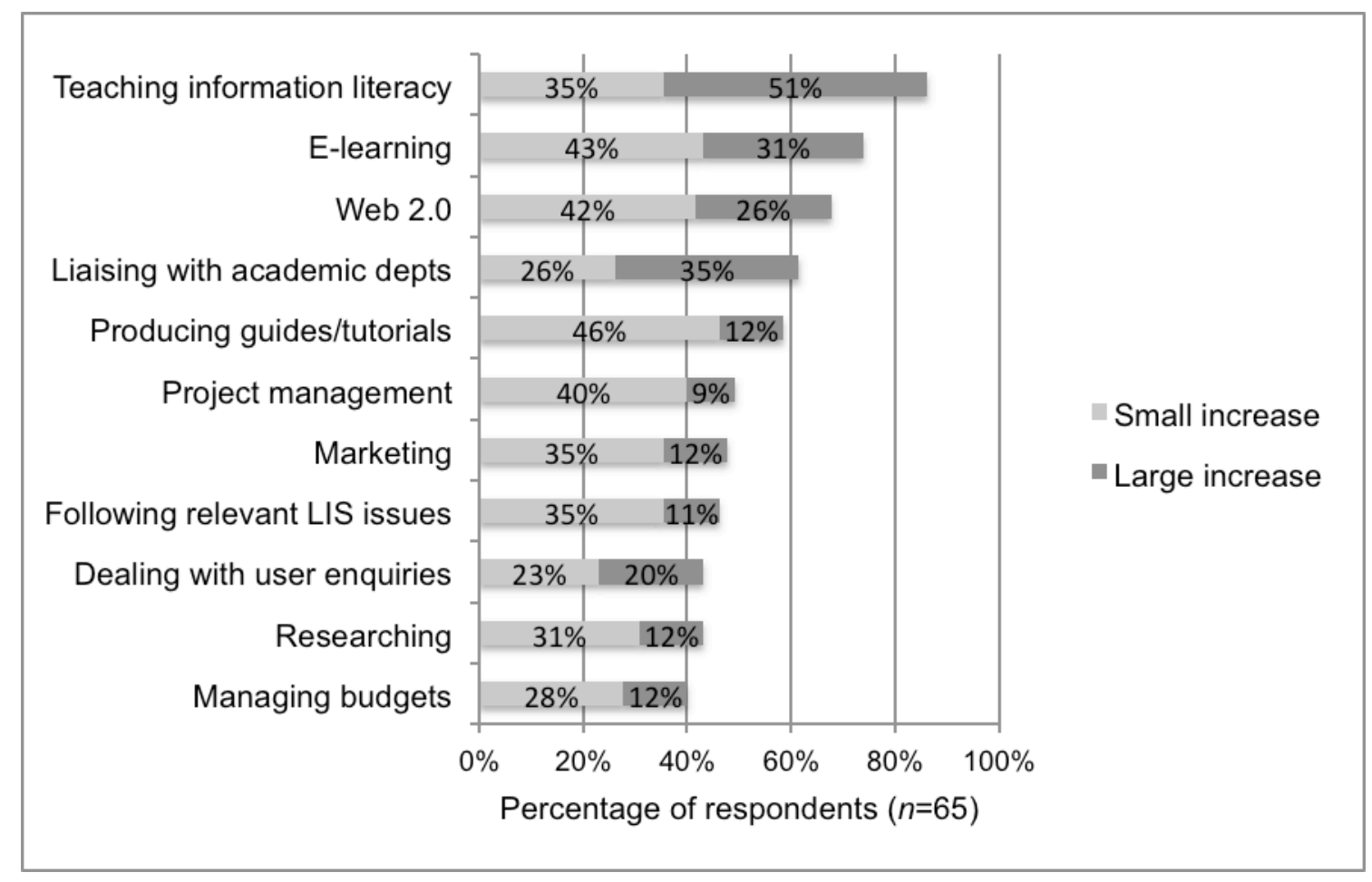

Fig. 2. Tasks showing highest increases in time

When asked about the main causes of the changes identified, interviewees confirmed the economic and technological drivers discussed in the literature. The most frequently mentioned causes were decreasing budgets [12,29]; the impact of technology on storing and searching for information, as well as on students' expectations and methods of learning 
[9,20,29,30]; and the growing credibility of IL as a concept that needs to be developed and taught by academic librarians. Thus LM4 mentioned "dwindling finance", while LM1 commented specifically on "shrinkage of information provision budgets"; SL8 mentioned "technological ubiquity" and LM7 highlighted "student use of technology". SL6 reported "greater acceptance and understanding by some academics of the importance of information skills/literacy" and SL8 said that students were "increasingly expecting everything to happen online but finding that in practice, the more online access they have, the more help from a qualified professional they need to navigate it", a point made by Nyamboga, Brown et al. and Fullerton and Leckie [31-33].

Several authors have predicted that the role of SL will disappear in the near future (for example, Heseltine [21], Martin [22] and more recently Feetham [9]) and some questionnaire and interview comments expressed similar sentiments. One LMQ respondent wrote, "it concerns me how many newly qualified LIS graduates' career aspirations are to be a subject librarian. At the start of a 30-40 year career, are they being educated to see a future in which such roles may no longer exist at all?" Another said that SLs needed to adapt to maintain the worth of their profession: "If subject librarians aren't out amongst the researchers and academics, helping and advocating in a positive way, they will be extinct fairly soon as they will lose their visibility and hence the essential supports from colleagues in academic departments". Similarly, LM6 wrote that "the facilitator/teacher/advisor role will develop further - but there is a real possibility that its value may not be recognised or seen as sufficient justification in an era of tight budgets".

Several SLs agreed with the LMs' emphasis on advocacy and justification. SL8 said that SLs needed to advocate the importance of teaching students IL to academics and senior management, who are often reluctant to accept its importance, "unless we show them the evidence clearly, repeatedly and loudly", arguing that in the future the SL job would involve "more advocacy of our skills to academic staff and senior management". In addition, SL3 mentioned the need to be able to "justify the service". Their comments here echo a growing emphasis on advocacy in the literature; for example, Pinfield [23] argues that SLs are increasingly engaged in advocacy for funding and the ALA includes advocacy in its Core Competences of Librarianship, not just as an area of knowledge and skill that librarians need, but presenting "advocacy for libraries, librarians, other library workers, and library services" as an important foundational activity for the profession [44].

\subsubsection{Librarians as teachers}

E-learning, Web 2.0 and guides/tutorials are all tools by which SLs aim to facilitate learning, and liaison with departments is often in order to establish how best to incorporate IL teaching into courses; LM5 and LM7 commented that SLs are increasingly "embedding" teaching within courses, while LM3 said that many SLs contribute to curriculum design. These five areas (rated highest for increased time commitment) can therefore all be considered aspects of the teaching role of the SL. Interview participants were asked about the type of teaching undertaken by SLs and both groups emphasised the wide range of teaching involved, from one-to-one sessions to lecturing to over one hundred students. Diversity was evident in the topics covered, for example "library inductions" (SL6), "basic IT" (SL5), "information retrieval" (LM1) and "referencing and plagiarism" (SL4); groups taught, for example "staff and students" (LM1) and "local sixth form students" (SL4); delivery methods, for example "creative use of learning technologies" (LM6) and "Elluminate sessions, Camtasia vodcasts" (SL3).

The interviews also asked participants how best to prepare SLs for their teaching role. SL1 said that many were not prepared: "I was thrown in the deep end like a lot of people and had to start swimming straight away!" SL6 said that there had been calls for SLs to have a 
formal teaching qualification. Four LMs mentioned formal training, such as a "PGCE or training certificate" (M2), as highly desirable, but not essential. Several SL and LM interviewees said that many teaching skills can be gained by direct experience and from observing, or being mentored by, colleagues on the job. Three SLs suggested attending teacher training courses while in post (as CPD). Bewick and Corrall [19] found that that around three-quarters of their sample of 82 UK SLs had learnt their teaching skills on the job, but many had also taken short courses (54\%) and/or extended programmes $(29 \%)$.

Three SLs mentioned the importance of library courses covering teaching skills and pedagogy. LM3 said this was important because "even if not teaching, subject librarians will contribute to curriculum design and development and pedagogic knowledge is useful here too". One SLQ respondent said, "once I had started work in my first professional post I realised that there were 'gaps' in my knowledge, which hadn't even been touched on in my course - most notably, designing and delivering training in IL". Around half of Bewick and Corrall's sample expressed a preference for pedagogical content to form a substantial part of their professional education, with 16 stating there should be a core unit on teaching and 11 favouring a designated pathway or set of units with this focus [19]. Several SL interviewees similarly mentioned the role of library courses, rather than separate teaching qualifications, in preparing librarians for teaching roles. For example, SL8 argued that "every librarianship course which claims to prepare students for working in HE [higher education] should include at least an optional module on teaching and learning". Our analysis of course documentation showed that only three programmes courses presently do.

\subsection{What skills, qualities and knowledge do subject librarians need?}

Questionnaire participants were asked to rate the importance of 20 generic personal skills and qualities for SLs on a four-point scale, ranging from "not important" to "very important". (The knowledge needed by SLs is discussed further in sections 4.4-4.5, which deal with participants' views on library-related education.) Fig. 3 shows the 10 attributes rated most highly by each group, based on the percentages of LMs and SLs rating them as "very important". Customer service, oral and written communication and interpersonal skills were judged "very important" by around $90 \%$ of all participants, which confirms many statements to this effect in the literature in recent decades $[10-15,42,45]$. The same attributes featured in the top ten for both groups and with almost identical rankings. The only significant difference here was the higher proportion of SLs rating Teaching skills as "very important" $(89.2 \%$, compared with $79.2 \%$ of LMs) and the higher proportion of LMs rating Teamwork skills as "very important" (91.7\%, compared with $78.5 \%$ of SLs). In the SL list, Teaching was thus ranked equal fourth, with Teamwork ranked eighth, whereas the LMs ranked Teamwork equal third and Teaching eighth.

As noted earlier, some commentators claim that having the right personal qualities and skills is the most important factor for success as an information professional $[10,11]$. Questionnaire participants were accordingly asked whether such generic skills and personal qualities were more or less important than specialist library-related skills and knowedge. The majority ( $66 \%$ of LMs and $54 \%$ of SLs) rated them as "equally important", but a substantial minority judged them to be either "slightly more important" or "much more important" than librarianship skills; one-fifth of the LMs and one-quarter of the SLs opted for the latter and only three participants in total rated general/personal skills as less important. 


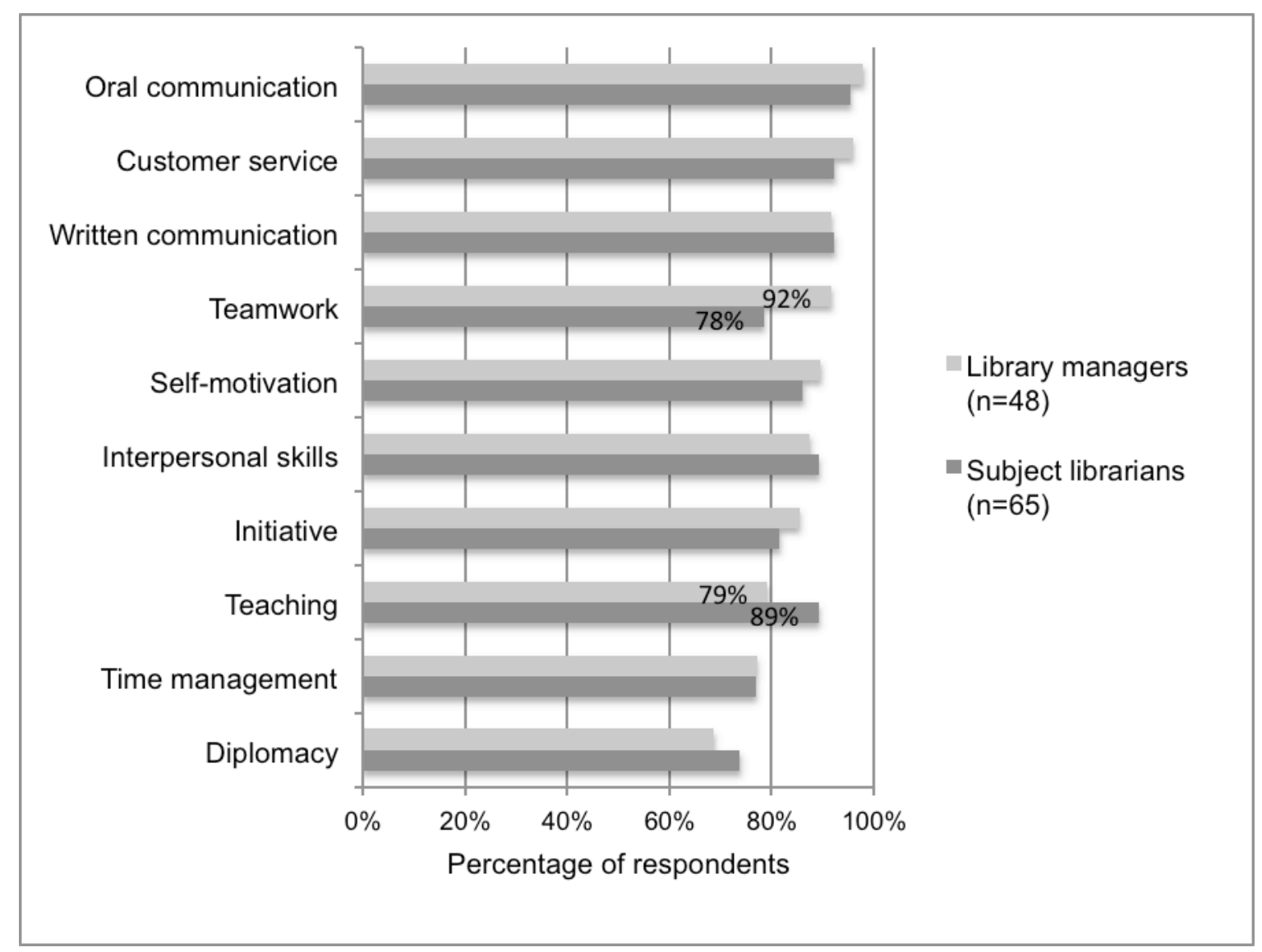

Fig. 3. Most important attributes for subject librarianship

To test this further, LMs, as potential recruiters/employers of SLs, were asked in their questionnaire how important "good personal skills and qualities" would be in comparison with a postgraduate library qualification and academic library experience when considering candidates for an entry-level professional job. Fig. 4 confirms the importance and priority attached to personal skills and qualities, but LIS educators may be encouraged by the fact that more than two-thirds of the sample regarded an academic library qualification as "very important" in this context, though they might be disappointed to see relatively little importance attached to how well candidates performed academically, with this apparently viewed as less important than work experience. It would be interesting to explore this further and also to investigate the relative priority attached to personal skills, relevant experience and attainment in professional education in other service professions (for example, law).

These results generally support Goulding et al.'s comment that "information and library employers place a high premium on personal attributes such as enthusiasm, initiative, flair, interpersonal skills and commercial awareness" [13] and also reflect the content analysis of library job advertisements carried out by Kennan et al. [14] and Lynch and Smith [15], which indicated that traditional librarianship skills were becoming less important and general/personal skills more important. However, this type of polarisation risks oversimplifying the situation. One LMQ respondent argued that the distinction between these types of skills was blurred: "subject librarians need generic skills as applied in a professional LIS context so there isn't a contradiction between the two". 


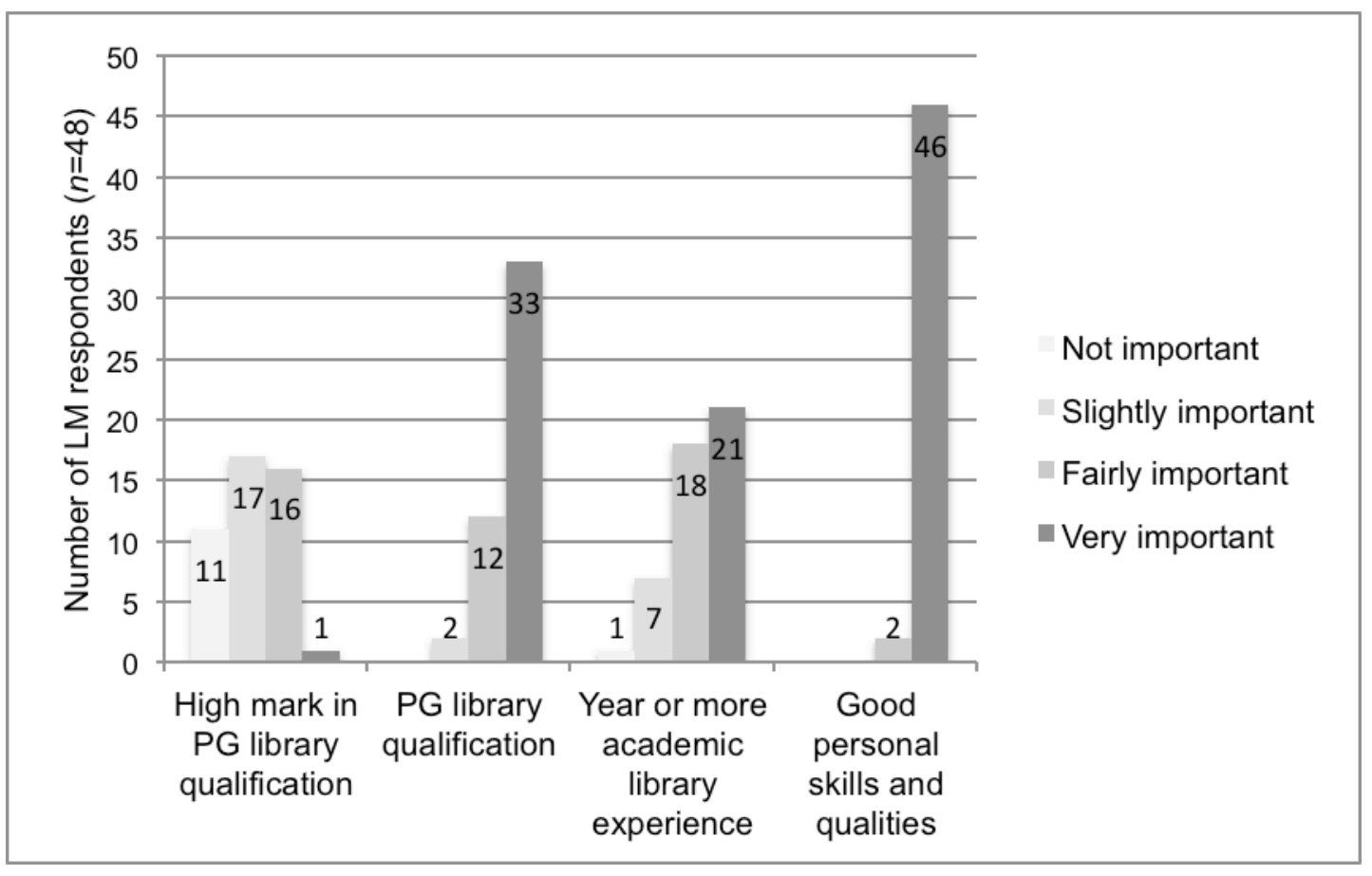

Fig. 4. Importance of candidate attributes in recruitment

Other survey participants added comments questioning whether such skills could be taught and/or developed. One SLQ respondent believed they could not, suggesting therefore that "the amount of time devoted to them [on their library course] was perhaps disproportionate when I could have been learning more tangible skills". Furthermore, one LMQ respondent questioned whether teaching such skills should be the responsibility of (postgraduate) library courses: "I don't think it is reasonable to blame iSchools for not achieving what should be basic graduate attributes". Another agreed, stating that "LIS courses should focus more on specific LIS skills development", thus bringing us back to the central question of the fitness for purpose of postgraduate librarianship education for the SL role, which is the focus of the final two sections of our discussion.

\subsection{What are library managers' and subject librarians' views on library education? 4.4.1. Quality of education}

Both questionnaires included a question near the beginning about the overall quality of postgraduate librarianship education. The LMs were asked whether their general opinion of UK provision was negative or positive and to locate this on a five-point scale (ranging from "very negative" to "very positive"), while the SLs were questioned more specifically about their satisfaction with the course that they attended, which they were asked to rate on a fourpoint scale (from "not satisfied" to "very satisfied"). The LMQ responses showed a striking degree of unanimity: 40 out of $48(83 \%)$ recorded "generally positive" assessments, with two "very positive" and only two "generally negative". (Four ticked the "no opinion" option.) There was more variation in the SMQ responses, with 18 (28\%) "very satisfied" and 36 $(55 \%)$ "very satisfied" verdicts, but with the same large majority of the sample $(83 \%)$ on the positive side; there ere eight "fairly unsatisfied". one "not satisfied". (Two of the 65 participants did not answer this question.) 


\subsubsection{Focus of programmes}

Both samples were then asked to rank the relative importance of five content areas of a librarianship curriculum, reflecting issues discussed in the literature, such as the balance between academic and vocational subject matter. Scores were assigned to responses using a five-point scale, where 5 represented the most important aspect of a programme for respondents. Fig. 5 displays the mean values for the two groups, showing similar opinions on the least and less important areas (library history, personal skills, generic skills), but showing some disagreement on the most important area, with LM scores tending to favour an information management focus and SLs prioritising vocational librarianship content, which could also be interpreted as a preference for course content of obvious practical relevance over subjects suggesting a more academic perspective.

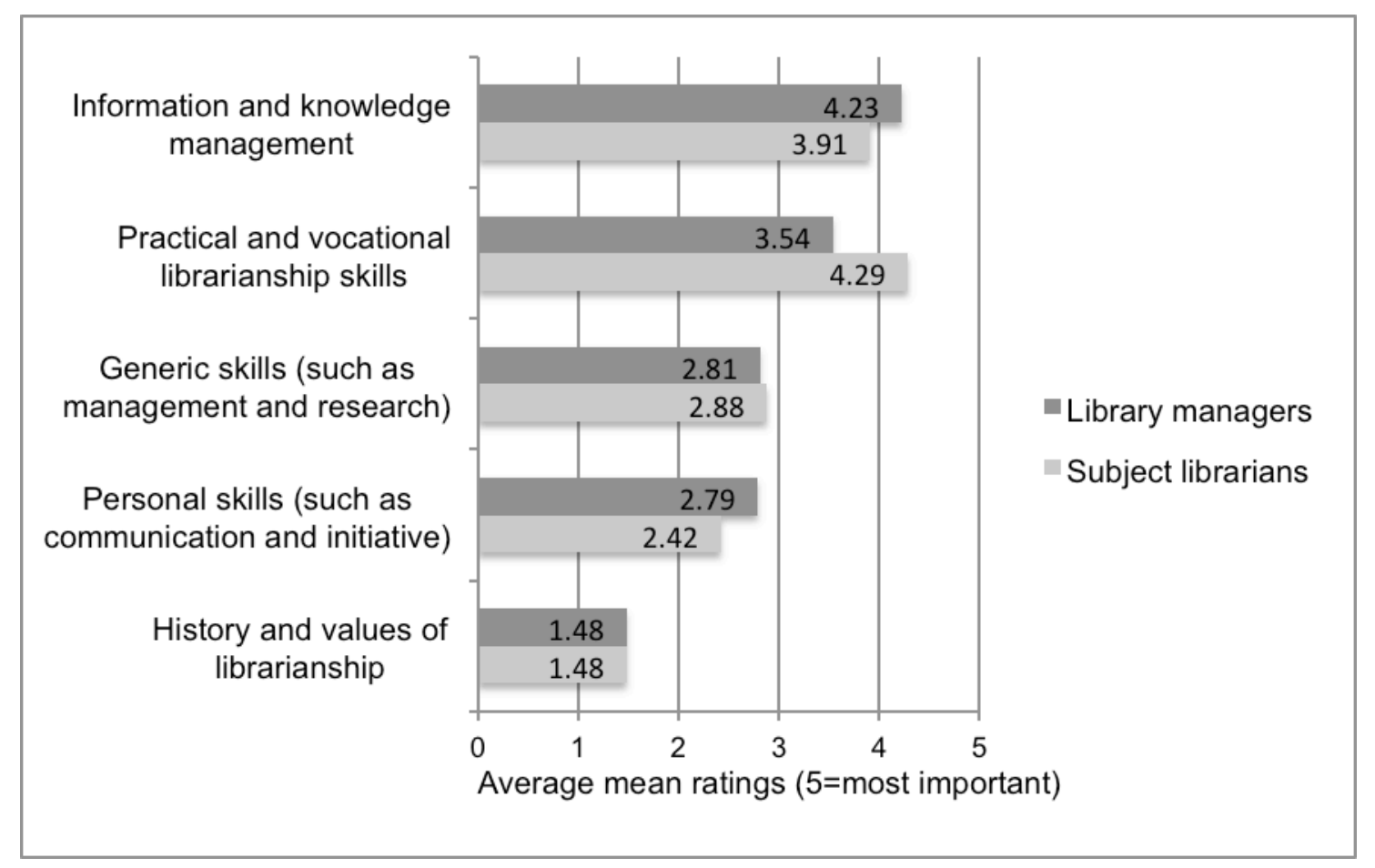

Fig. 5. Relative importance of programme content areas

The raw data reveal the extent of the differences more clearly: $60 \%$ of SLs thought teaching practical and vocational librarianship skills was most important, in comparison with only $33 \%$ of LMs; and 54\% of LMs ranked teaching information and knowledge management as most important, compared with $31 \%$ of SLs. Audunson suggests that although a focus on theory during library courses may mean students are less prepared for library work after graduation, in the long term their contribution and understanding may be greater because of their increased theoretical knowledge [17]. One SLQ comment confirms here how perceptions of value may change over time: "my appreciation for some aspects of the course has grown over time - the management modules were deathly dull when I studied them, but have given me some sense of context in which to place my current organisational practices". This reflects Loughridge's finding that some theoretical aspects of library courses such as management, which seemed to be irrelevant in respondents' first professional library posts, later become useful when they moved into more senior roles [24].

The interviews specifically asked respondents whether they thought librarianship education had become too detached from actual library work and too focused on theoretical information management/science. LM2 commented that "theory is important, as is reflection. 
Actual library work can be learnt on the job". LM6 reinforced this view, arguing that "you need some theoretical underpinning to practice; if you don't get that during the academic part of your training, when will you?" There was also SL support for theoretical content, for example: SL 7 wrote, "because change is so rapid now, it would be impossible to train students in everything they might need in the work situation, so, in some ways, it is the theoretical aspects that can best be covered in library school".

\subsubsection{Criticisms of provision}

In order to test more extensively the level of agreement among practitioners with opinions on professional education found in the literature, both questionnaires presented respondents with a set of 11 statements representing views commonly expressed about LIS programmes and asked whether they agreed with them. Table 1 shows a similar pattern of responses for the two groups, but overall not much support for most of the views expressed; only three of the 11 statements attracted support from one-third or more of participants from each group.

Table 1. Agreement with published views of education.

\begin{tabular}{|c|c|c|}
\hline \multirow[b]{2}{*}{ Statements about LIS education } & \multicolumn{2}{|c|}{$\begin{array}{l}\text { Number of respondents } \\
\text { ( } \% \text { of relevant sample) }\end{array}$} \\
\hline & $\begin{array}{l}\text { Library } \\
\text { Managers } \\
(n=48)\end{array}$ & $\begin{array}{l}\text { Subject } \\
\text { Librarians } \\
(n=65)\end{array}$ \\
\hline $\begin{array}{l}\text { It is not quick enough to adapt to changes in LIS practice and } \\
\text { thinking }\end{array}$ & $\begin{array}{c}27 \\
(56)\end{array}$ & $\begin{array}{c}32 \\
(49)\end{array}$ \\
\hline $\begin{array}{l}\text { It should aim more to develop students' personal skills and } \\
\text { qualities such as communication, initiative and creativity }\end{array}$ & $\begin{array}{c}22 \\
(46)\end{array}$ & $\begin{array}{c}22 \\
(34)\end{array}$ \\
\hline It is too theoretical/academic & $\begin{array}{c}20 \\
(42)\end{array}$ & $\begin{array}{c}22 \\
(34)\end{array}$ \\
\hline $\begin{array}{l}\text { It is becoming increasingly focused on information science } \\
\text { rather than traditional librarianship }\end{array}$ & $\begin{array}{c}11 \\
(23)\end{array}$ & $\begin{array}{c}19 \\
(29)\end{array}$ \\
\hline $\begin{array}{l}\text { It should teach more generic skills such as management and } \\
\text { research }\end{array}$ & $\begin{array}{c}10 \\
(21)\end{array}$ & $\begin{array}{l}17 \\
(26)\end{array}$ \\
\hline $\begin{array}{l}\text { It is being positively influenced by a growing focus on } \\
\text { information science }\end{array}$ & $\begin{array}{c}8 \\
(17)\end{array}$ & $\begin{array}{l}15 \\
(24)\end{array}$ \\
\hline $\begin{array}{l}\text { It is too susceptible to fads and trends in LIS practice and } \\
\text { thinking }\end{array}$ & $\begin{array}{c}7 \\
(15)\end{array}$ & $\begin{array}{c}9 \\
(14)\end{array}$ \\
\hline It is too focused on librarianship principles & $\begin{array}{c}4 \\
(8)\end{array}$ & $\begin{array}{c}7 \\
(11)\end{array}$ \\
\hline It is not focused enough on librarianship principles & $\begin{array}{l}3 \\
(6)\end{array}$ & $\begin{array}{c}5 \\
(8)\end{array}$ \\
\hline $\begin{array}{l}\text { It is being negatively influenced by a growing focus on } \\
\text { information science }\end{array}$ & $\begin{array}{c}2 \\
(4)\end{array}$ & $\begin{array}{c}4 \\
(6)\end{array}$ \\
\hline It is too practical/vocational & $\begin{array}{c}1 \\
(3)\end{array}$ & $\begin{array}{c}0 \\
(0)\end{array}$ \\
\hline
\end{tabular}

LIS educators are often criticised for being slow to respond to the needs of the library profession $[12,45]$ and around half of our respondents agreed with this view, while more than one-third thought there should be more focus on personal skills and qualities. The same 
proportion thought education was too theoretical/academic, but an interesting point here is the higher proportion of LMs agreeing with this statement, which is not entirely consistent with views evident in answers to other questions, confirming the range of opinion that exists both between and within different stakeholder groups on this issue. However, there was very little support for the idea that librarianship education has been negatively influenced by a growing focus on information science, a view expressed by some traditionalists such as Gorman [18,39]. Indeed, one SLQ respondent said, "I think the distinction between librarianship and information science was already blurred and, as such, I feel they are as one rather than competing elements". The counter view, exemplified by the perception reported by Budd that rather than being too theoretical, "education for librarianship (in general) has been...too focused on the vocational side, with skills emphasised at the expense of principles" [5] attracted minimal support, with only one LM agreeing with this,

\subsection{What do library managers and subject librarians think should be taught on library- related courses?}

\subsubsection{Core topics}

Questionnaire participants were given a list of 23 subjects/topics and asked whether they should be included in the library curriculum as a core unit/course, an elective unit, not a specific unit or not part of the programme. Table 2 shows the ten topics with the highest scores from each group for inclusion as core units (arranged in descending order of popularity). The most noticeable difference of opinion between the samples was that a much higher percentage of SLs (63\%) than LMs (23\%) said that Teaching/Pedagogy should be a core unit. Possibly fewer LMs think teaching is a core skill needed by all librarians; or perhaps SLs are simply more aware of librarians' need for teaching skills because they are usually the ones doing the teaching.

Given that the results showed Cataloguing and Classification were not a frequent part of most SLs' jobs, it was interesting that more than half of the SL sample (51\%) and more than one-third of LMs (38\%) selected this topic for inclusion as a core unit, which supports Bowman's [40] and Gorman's [18] argument that it provides the foundation for work in other areas, such as enquiries and collections. Key areas of agreement were that around threequarters of LMs and SLs said Collection Management should be a core unit and around twothirds of LMs and SLs said that Digital Libraries should be a core unit. Perhaps not surprisingly, LMs gave higher ratings to Management and SLs to Information Literacy, but it was also interesting that SLs put Research Methods on a par with Management and that a significantly higher proportion of SLs $(80 \%)$ than LMs (63\%) selected this as a core unit.

There was very low support for Library History being a core unit, with only one SL and one LM specifying this. The strength of support for IL being a core unit (83\% of LMs and $92 \%$ of SLs) is not surprising given its centrality to the SL role, but this exposes a significant mismatch between supply and demand in the UK, as our document analysis of course content showed that only two universities - Sheffield and Liverpool John Moores - had IL as a specific core unit in their postgraduate library-related programmes at the time of the study. In addition, several institutions do not currently provide a core unit wholly devoted to collection management and/or information services. 
Table 2. Core unit priorities for LIS programmes

\begin{tabular}{|c|c|c|c|c|c|}
\hline & Library Managers $(n=48)$ & & & Subject Librarians $(n=65)$ & \\
\hline Rank & Topic & $\begin{array}{l}\text { No. } \\
(\%)\end{array}$ & Rank & Topic & $\begin{array}{l}\text { No. } \\
(\%)\end{array}$ \\
\hline 1 & $\begin{array}{l}\text { Management/ } \\
\text { library management }\end{array}$ & $\begin{array}{c}45 \\
(94)\end{array}$ & $1=$ & Information literacy & $\begin{array}{l}60 \\
(92)\end{array}$ \\
\hline 2 & Information retrieval & $\begin{array}{c}43 \\
(90)\end{array}$ & $1=$ & Information retrieval & $\begin{array}{c}60 \\
(92)\end{array}$ \\
\hline 3 & Information literacy & $\begin{array}{c}40 \\
(83)\end{array}$ & $3=$ & $\begin{array}{l}\text { Management/ } \\
\text { library management }\end{array}$ & $\begin{array}{c}52 \\
(80)\end{array}$ \\
\hline 4 & Collection management & $\begin{array}{l}35 \\
(73)\end{array}$ & $3=$ & Research skills/methods & $\begin{array}{c}52 \\
(80)\end{array}$ \\
\hline 5 & Digital libraries & $\begin{array}{c}32 \\
(67)\end{array}$ & 5 & Collection management & $\begin{array}{c}49 \\
(75)\end{array}$ \\
\hline 6 & Research skills/methods & $\begin{array}{c}30 \\
(63)\end{array}$ & 6 & Digital libraries & $\begin{array}{c}43 \\
(66)\end{array}$ \\
\hline $7=$ & $\begin{array}{l}\text { Library and information } \\
\text { services }\end{array}$ & $\begin{array}{c}23 \\
(48)\end{array}$ & 7 & $\begin{array}{l}\text { Library and information } \\
\text { services }\end{array}$ & $\begin{array}{c}42 \\
(65)\end{array}$ \\
\hline $7=$ & Professional issues & $\begin{array}{c}23 \\
(48)\end{array}$ & 8 & Teaching/pedagogy & $\begin{array}{c}41 \\
(63)\end{array}$ \\
\hline 9 & Project management & $\begin{array}{c}22 \\
(46)\end{array}$ & 9 & Professional issues & $\begin{array}{c}39 \\
(60)\end{array}$ \\
\hline 10 & Information law & $\begin{array}{c}19 \\
(40)\end{array}$ & 10 & $\begin{array}{l}\text { Cataloguing and } \\
\text { classification }\end{array}$ & $\begin{array}{c}33 \\
(51)\end{array}$ \\
\hline
\end{tabular}

\subsubsection{Course standardisation}

Participants were also asked whether they thought library courses should be standardised to the extent that each institution would teach broadly the same core topics. A similarly small majority of both groups (52\% of LMs and $55 \%$ of SLs) supported this proposal, but a substantial minority of LMs (17 or 35\%) and a significant number of SLs (14 or 22\%) were against this. (The rest either ticked "Don't know" or did not respond to the question.)

Comments from interviewees on this question confirmed this diversity of opinion. LM1 said that courses rightly tailored their content to a particular market or aspect of LIS. LM2, LM6 and LM7 believed that rigidly standardised courses would not be appropriate, since LIS covers such a range of jobs. However, Gorman argues that there needs to be greater standardisation so that employers know that all library graduates will have the same core skills and knowledge [18]. Several SLs (SL1, SL3, SL5, SL6 and SL7) said that variability was beneficial to broaden students' career options and accommodate their interests, but thought that there should at least be a common core that all courses teach. Without this core, SL1 asked, "how are future employers to know how good your degree/qualification is if the courses are all completely different?" Similarly, LM3 said that without a significant amount of standardisation, "it is difficult to be clear about what a new [librarianship] professional does or does not know".

Several LMs (LM3, LM4 and LM5) also commented that the idea of librarianship as a profession is undermined by course variability. LM5, for instance, said that "it is hard to 'sell' the importance of professionalism if we have failed to define it ourselves and [if we do not] have a standardised approach to education and qualification". However, LM4 said that 
although variability did undermine the idea of librarianship as a profession, this was not a bad thing: "I really don't think we should see ourselves as professionals any more than historians or facilities managers should...leave that to doctors and lawyers".

\section{Conclusion}

The purpose of this study was to investigate whether postgraduate librarianship education in the UK is suitable preparation for the role of subject librarian. This involved investigating several areas: the content of postgraduate library courses in the UK; the role of SLs; the skills, qualities and knowledge needed; practitioner and management views on librarianship education and on what should be taught on such courses. The investigation included document analysis of course content, online surveys of SLs and library managers; and email interviews of both SLs and LMs.

Many of the results reflect and confirm what is already reported in the literature: for example, how and why the role of SL has changed in recent years, that there is some unease about the future of the SL role, and that good personal and general skills are essential for academic and subject librarians.

However, there are some areas where this study adds value to the literature. As far as the authors are aware, it was unique in simultaneously obtaining the views of SLs and LMs on a range of issues relating to the SL role and to librarianship education. This enabled comparisons between the two samples' answers to the same questions, and differences of opinion on librarianship education and subject librarianship to be identified. For example, it was especially interesting that SLs and LMs had significantly different opinions about the main purpose of librarianship education, with a much higher percentage of LMs (54\%) than SLs (31\%) believing it to be teaching information and knowledge management, and a much higher percentage of SLs (60\%) than LMs (33\%) believing it to be teaching practical and vocational librarianship skills. There were also notable differences of opinion regarding library course curricula. Most striking was that $63 \%$ of SLs said that teaching/pedagogy should be a core module, compared to just $23 \%$ of LMs.

Document analysis showed that course content varies significantly between universities. Many respondents were in favour of standardised courses that have a common core, but also have optional modules that allow students to specialise to an extent, or believed that there should be a set number of core modules to which universities could add their own unique core and optional modules. This would seem an appropriate approach; it would assure employers that all library course graduates had a core set of skills and knowledge, allow programmes to retain their identity and individuality, and enable students to choose a programme that suited their interests and future career plans. It is evident that the frameworks provided by professional bodies, such as the ALA and (particularly) CILIP, are too broad to ensure any real standardisation of library courses

A further study could compare professional education for SLs in the UK and other countries (for example, the US, Canada and Australia), involving data collection from participants in the respective professional communities. For greater relevance and validity, the different strands of the study could also focus specifically on the appropriate country's literature, rather than taking a broad view of the field as was done in this study. A larger-scale study could investigate programme content in more depth, by collecting data from programme directors and course leaders, rather than limiting the analysis to website documentation. Additional studies could evaluate educational provision nationally and internationally for other key library roles, including new jobs arising from digital library developments. 


\section{Acknowledgements}

The authors gratefully acknowledge the co-operation and contributions of the university library staff who participated in this survey, particularly the library managers and subject librarians who also volunteered for and participated in the interviews.

\section{References}

[1] F. Blin, Academic libraries, in: Global Library and Information Science: A Textbook for Students and Educators, I. Abdullahi, ed., Munich: K.G. Saur, 2009, pp. 329-342.

[2] L.F. Li, S. Leung and G. Tam, Promoting information literacy skills through web-based instruction: the Chinese University of Hong Kong library experience, Library Management 28(8/9) (2007), 531-539.

[3] J. Starr, Measure of change: comparing library job advertisements of 1983 and 2003, LIBRES: Library and Information Science Research Electronic Journal 14(2) (2004), http://libres.curtin.edu.au/libres14n2/Starr final.htm.

[4] S.J. Bell and J. Shank, The blended librarian: a blueprint for redefining the teaching and learning role of academic librarians, College \& Research Libraries News 65(7) (2004), 372-375, http://crln.acrl.org/content/65/7/372.full.pdf.

[5] J.M. Budd, The Changing Academic Library: Operations, Culture, Environments, Chicago: Association of College and Research Libraries, 2005.

[6] R. Newton, Developing information literate off-campus learners: pedagogical issues and current practice, Libri 57(3) (2007), 140-164.

[7] A. Paterson, (1999) Ahead of the game: developing academic library staff for the 21st century, in: The Future of Libraries in Human Communication: Proceedings of the 20th IATUL Conference, Chania, Crete, Greece, 1999, http://www.iatul.org/conferences/pastconferences/1999proceedings.asp.

[8] J. Akeroyd, The future of academic libraries, Aslib Proceedings 53(3) (2001), 79-84.

[9] M. Feetham, The subject specialist in higher education - a review of the literature, in: Subject Librarians: Engaging with the Learning and Teaching Environment, P. Dale, M. Holland and M. Matthews, eds, Aldershot: Ashgate, 2006, pp. 3-17.

[10] P. Garrod, Skills for new information professionals (SKIP): an evaluation of the key findings, Program: Electronic Library and Information Systems 32(3) (1998), 241-263.

[11] A. Kanczak and K. Szołtysik, Is there a place for the librarian in the library of the 21st century?, World Libraries 16(1-2) (2006), http://www.worlib.org/vol16no12/kanczak_v16n1-2.shtml.

[12] G. Hallam and P. Calvert (2009) Australia: LIS education, in: Global Library and Information Science: A Textbook for Students and Educators, I. Abdullahi, ed., Munich: K.G. Saur, 2009, pp. 288-303.

[13] A. Goulding, B. Bromham, S. Hannabuss and D. Cramer, Supply and demand: the workforce needs of library and information services and personal qualities of new professionals, Journal of Librarianship and Information Science 31(4) (1999), 212223.

[14] M.A. Kennan, P. Willard and C.S. Wilson, What do they want? A study of changing employer expectations of information professionals, Australian Academic \& Research Libraries 37(1) (2006), 17-37, http://www.alia.org.au/publishing/aarl/37.1/kennan.willard.pdf.

[15] B.P. Lynch and K.R. Smith, The changing nature of work in academic libraries, College \& Research Libraries 62(5) (2001), 407-420.

[16] M. Mathews and H. Pardue, The presence of IT skill sets in librarian position announcements, College \& Research Libraries 70(3) (2009), 250-257. 
[17] R. Audunson, Library and information science education - discipline, profession, vocation? Journal of Education for Library and Information Science 48(2) (2007), 94 107.

[18] M. Gorman, Our Enduring Values: Librarianship in the 21st Century, Chicago: American Library Association, 2000.

[19] L. Bewick and S. Corrall, Developing librarians as teachers: a study of their pedagogical knowledge, Journal of Librarianship and Information Science 42(2) (2010), 97-110.

[20] R. Biddescombe, Learning support professionals: the changing role of subject specialists in UK Academic Libraries, Program: Electronic Library and Information Systems 36(4) (2002), 228-235.

[21] G. Hardy and S. Corrall, Revisiting the subject librarian: a study of English, Law and Chemistry, Journal of Librarianship and Information and Information Science 39(2) (2007), 79-91.

[22] J.V. Martin, Subject specialization in British university libraries: a second survey, Journal of Librarianship and Information Science 28(3) (1996), 159-169.

[23] S. Pinfield, The changing role of subject librarians in academic libraries, Journal of Librarianship and Information Science 33(1) (2001), 32-38.

[24] B. Loughridge. Employment and career surveys: some reflections on their value and relevance'. Journal of Librarianship and Information Science 22(2) (1990), 71-90.

[25] B. Loughridge, Life after Sheffield: follow-up studies of masters graduates, Journal of Librarianship and Information Science 35(3) (2003), 165-170.

[26] B. Loughridge and J. Sutton, The careers of MA graduates: training, education and practice, Journal of Librarianship and Information Science 20(4) (1988), 255-269.

[27] K.L. Quarmby, P. Willett and F. Wood, Follow-up study of graduates from the MSc Information Management programme at the University of Sheffield, Journal of Information Science 25(2) (1999), 147-155.

[28] M. Simmons, An investigation of postgraduate librarianship education in the UK and its relevance to the role of subject librarian, Masters Dissertation, University of Sheffield, 2010

[29] I.M. Johnson, Peering into the mist and struggling through it - the education and training of the future information professional, Journal of Librarianship and Information Science 29(3) (1997), 3-7.

[30] V. Reyes, The future role of the academic librarian in higher education, Portal: Libraries and the Academy 6(3) (2006), 301-309.

[31] A. Fullerton and G.J. Leckie, Information literacy and higher education, in: Encyclopedia of Library and Information Science, vol. 70, supp. 3, A. Kent, ed., New York: Marcel Dekker, 2001, pp. 190-205.

[32] C.M. Nyamboga, Information skills and information literacy in Indian university libraries, Program: Electronic Library and Information Systems 38(4) (2004), 232-239.

[33] C. Brown, T.J. Murphy and M. Nanny, Turning techno-savvy into info-savvy: authentically integrating information literacy into the college curriculum, Journal of Academic Librarianship, 29 (6) (2003), 386-398.

[34] R. Audunson, R. Nordie and I.C. Spangen, The complete librarian: an outdated species? LIS between profession and discipline, New Library World 104(6) (2003), 195-202.

[35] B. Crowley and B. Brace, A choice of futures: is it libraries versus information?, American Libraries 30(4) (1999), 76-79.

[36] Chartered Institute of Library and Information Professionals, CILIP Accreditation Instrument, London: CILIP, 2005, http://www.cilip.org.uk/filedownloadslibrary/qualifications/accreditation\%20(web).pdf. 
[37] American Library Association, Standards for Accreditation of Master's Programs in Library \& Information Studies, Chicago: ALA, 2008, http://www.ala.org/ala/educationcareers/education/accreditedprograms/standards/index. $\mathrm{cfm}$.

[38] I. Stoica, The education of librarians: notes and opinions resulting from visits to some library schools, IFLA Journal, 18(4) (1992), 357-360.

[39] M. Gorman, Whither library education?, New Library World 105(9/10) (2004), 376380

[40] J.H. Bowman, Education and training for cataloguing and classification in the British Isles, in: Education for Library Cataloguing - International Perspectives, D.D. Sun and R.C. Carter, eds, Binghampton: Haworth Press, 2006, pp. 309-334.

[41] Association for Library Collections \& Technical Services, Educational policy statement, 1995, http://www.ala.org/ala/mgrps/divs/alcts/about/governance/policies/cepolicy.cfm

[42] M.L. Rice-Lively and D. Racine, The role of academic librarians in the era of information technology, Journal of Academic Librarianship, 23(1) (1997), 31-41.

[43] Chartered Institute of Library and Information Professionals, CILIP Body of Professional Knowledge, London: CILIP, 2004, http://www.cilip.org.uk/sitecollectiondocuments/PDFs/qualificationschartership/BPK.p df.

[44] American Library Association, ALA's Core Competences of Librarianship, Chicago: ALA, 2009, http://www.ala.org/ala/educationcareers/careers/corecomp/corecompetences/index.cfm

[45] B. Cronin, The Education of Library-Information Professionals: A Conflict of Objectives? London: Aslib, 1982. 